\title{
PEMODELAN WAKTU PEMELIHARAAN PENCEGAHAN OPTIMAL DENGAN MEMPERTIMBANGKAN KERUGIAN PRODUKSI
}

\author{
A. Soepardi ${ }^{1}$, Puryani $^{2}$, M. Chaeron ${ }^{3}$, P.L. Puspita ${ }^{4}$ \\ 1,2,3,4) Fakultas Teknologi Industri, Jurusan Teknik Industri, UPN “Veteran” Yogyakarta \\ Jl. Babarsari No. 2 Tambakbayan Yogyakarta 55281 \\ Email: apriani.soepardi@gmail.com
}

\begin{abstract}
ABSTRAK
Penelitian ini berhubungan dengan penyusunan model total biaya pemeliharaan untuk menentukan interval pemeliharaan pencegahan yang optimal dengan kriteria minimasi total biaya. Komponen biaya pemeliharaan yang dolibatkan adalah biaya pemeliharaan pencegahan, biaya pemeliharaan perbaikan, dan biaya kerugian karena lamanya downtime alat. Karakateristik model yang dibangun dipengaruhi oleh pola kerusakan dan total downtime alat. Kerusakan alat dimodelkan dengan pendekatan black-box dengan anggapan mengikuti fungsi intensitas Power Law Process. Sedangkan downtime alat tergantung pada lamanya kegiatan pemeliharaan pencegahan dan pemeliharaan perbaikan yang dikarakteristikkan oleh distribusi lamanya waktu perbaikan. Selain dilakukan penentuan interval pemeliharaan optimal, penelitian ini juga memberikan analisis sensitivitas terhadap semua parameter model yang digunakan.
\end{abstract}

Kata kunci : pendekatan black box, downtime, power law process, pemeliharaan pencegahan, pemeliharaan perbaikan

\begin{abstract}
This study relates to the preparation of the total cost of maintenance model to determine preventive maintenance time interval with the total cost minimization criterion. Component maintenance cost consists of the cost of preventive maintenance, corrective maintenance, and cost of losses due to equipment downtime duration. Model characteristics are influenced by the pattern of equipment failure and downtime. Equipment failure is modeled by a black-box approach by assumption that following intensity function as Power Law Process. Whereas equipment downtime depends on the length of preventive and corrective maintenance activities that characterized by repair time distribution.. In addition to the optimization of preventive maintenance time intervals, this study also provides a sensitivity analysis to all model parameters that used.
\end{abstract}

Key words: black box approach, downtime, power law process

\section{PENDAHULUAN}

Menurut MIL-STD 721B pemeliharan diartikan sebagai semua kegiatan untuk mempertahankan item pada, atau memperbaikinya ke kondisi yang telah dispesifikasikan. Pemeliharaan pencegahan (preventive maintenance) adalah kegiatan untuk mempertahankan sistem pada kondisi yang telah dispesifikasikan, dengan cara pemeriksaan sistematis, deteksi, dan pencegahan kerusakan. Sedangkan pemeliharaan korektif (corrective maintenance) adalah semua tindakan yang dilakukan untuk memperbaiki kerusakan item (Osaki, 1992). Berdasarkan pengertian di atas, pada prinsipnya kegiatan pemeliharaan adalah menghindari terjadinya kerusakan (breakdown) tidak terencana dan menekan waktu kerusakan (downtime) sekecil mungkin.

Untuk dapat melakukan tindakan pemeliharaan yang optimal diperlukan dukungan beberapa faktor, yaitu : biaya pemeliharaan, dalam hal ini adalah dana pemeliharaan yang tersedia, ketersediaan suku cadang (spare part) untuk mendukung kelancaran proses perbaikan maupun penggantian komponen, keterampilan operator yang memadai, dan kebijakan pemeliharaan yang diterapkan oleh perusahaan. Jika faktor-faktor tersebut dapat dipenuhi maka keuntungan yang akan diperoleh dari kegiatan pemeliharaan adalah 
penurunan jumlah terjadinya kerusakan peralatan produksi sehingga waktu ketersediaan (availability) alat untuk pemakaian relatif lama. Di samping itu, dengan penerapan kebijakan pemeliharaan yang tepat diharapkan dapat memperpanjang umur alat (Rao, 1992)

Salah satu permasalahan dalam kebijakan pemeliharaan adalah penentuan interval waktu pemeliharaan pencegahan yang tepat. Jika interval pemeliharaan pencegahan terlalu pendek maka frekuensi pelaksanaan PM akan semakin tinggi sehingga biaya kegiatan PM semakin naik. Sedangkan jika interval pemeliharaan pencegahan terlalu lama, maka kemungkinan terjadinya kerusakan akan bertambah yang berakibat pada kenaikan jumlah kerusakan sehingga downtime juga semakin lama yang berdampak pada turunnya tingkat ketersediaan alat (Murthy dan Asgharizadeh, 1998). Oleh karena itu dalam rangka meminimasi biaya pemeliharaan, interval waktu PM optimal menjadi salah satu kajian penting dalam penyusunan model pemeliharaan.

\section{METODOLOGI PENELITIAN}

Model kerusakan dan total downtime alat yang digunakan pada penelitian ini mengacu pada model estimasi biaya jasa pemeliharaan alat berat wheel loader yang diusulkan oleh Soepardi dan Iskandar (2002). Pada model ini, biaya yang dilibatkan terdiri dari lima komponen, yaitu biaya PM, biaya penggantian komponen (termasuk biaya tenaga kerjanya), biaya CM, biaya tenaga kerja yang melakukan kegiatan PM dan CM, dan biaya penalti. Biaya penalti ini muncul jika tingkat ketersediaan alat kurang dari batas minimal yang ditetapkan berdasarkan kesepakatan antara pemilik alat dan penyedia jasa pemeliharaan.

Pada penelitian ini diasumsikan bahwa biaya PM dan CM sudah termasuk biaya tenaga kerjanya. Selain itu, model ini tidak melibatkan biaya penggantian komponen. Sedangkan untuk kriteria terjadinya kerugian dilihat dari aspek lamanya downtime alat sehingga mengakibatkan kerugian produksi (loss production).

\section{Penentuan Model Kerusakan}

Kerusakan alat dimodelkan dengan pendekatan black box, yaitu alat pada setiap titik waktu hanya memiliki status rusak atau baik. Jika rusak akan dilakukan tindakan pemeliharaan korektif (CM) dengan minimal repair, dimana laju kerusakan alat setelah diperbaiki sama dengan laju kerusakan alat sebelum mengalami kerusakan. Tindakan korektif dapat berupa perbaikan komponen maupun penggantian komponen.

Tindakan minimal repair yang dilakukan tehadap alat biasanya hanya memperbaiki atau mengganti sebagian kecil dari keseluruhan komponen yang menyusun alat. Hal ini menyebabkan sistem kurang lebih berada pada status yang sama seperti sebelum mengalami kerusakan. Waktu antar kerusakan tidak lagi terdistribusi secara independen dan identik. Kondisi sistem akan terus menurun (deteriorating) sehingga nilai $X_{i}$ yang berurutan akan berkorelasi dan akan menunjukkan suatu tren sehingga situasi ini dapat dimodelkan sebagai NonHomogeneous Poisson Process (NHPP) dengan fungsi intensitas tertentu (Osaki, 1992) Fungsi intensitas $\rho(t)$ adalah ekspektasi laju perubahan jumlah kerusakan terhadap waktu dan jika dianggap mengikuti Power Law Process (Ebeling, 1997), maka:

$$
\rho(t)=a b T^{b-1}
$$

\section{Penentuan Model Total Downtime}

Setiap CM menyebabkan alat berada pada status down dan lama alat berada pada status tersebut bersifat acak. Secara umum, ekspektasi downtime yang disebabkan CM adalah lamanya waktu perbaikan rata-rata dikalikan dengan ekspektasi jumlah kerusakan selama interval tertentu. Downtime alat karena CM ke-i dinyatakan sebagai $\mathrm{X}_{\mathrm{i}}(\mathrm{i}=1,2, \ldots)$. 
$X$ adalah variabel random yang menyatakan waktu perbaikan atau lama downtime untuk satu kerusakan dengan fungsi kepadatan probabilitas $f(x)$ tertentu. Ekspektasi nilai $X$ didefinisikan sebagai berikut:

$$
E(X)=\int_{-\infty}^{\infty} x f(x) d x
$$

Jika $X$ dianggap berdistribusi eksponensial, maka ekspektasi nilai $X$ atau rata-rata lama downtimenya adalah:

$$
E(X)=\int_{-\infty}^{\infty} x f(x) d x=\int_{0}^{\infty} x \lambda e^{-\lambda x} d x=\frac{1}{\lambda} \int_{0}^{\infty} \lambda e^{-\lambda x}(\lambda x) d x=\frac{1}{\lambda}
$$

Dengan demikian ekspektasi lama downtime karena CM adalah:

$$
E[C(T)]=E(X) \int_{0}^{T} \rho(t) d t
$$

Setiap kejadian PM juga menyebabkan alat berada pada status down dan lama alat berda pada status tersebut konstan. Jika $\mathrm{P}(T)$ adalah total lama alat berada pada status down yang disebabkan kejadian PM sampai dengan saat $T$, yang dinyatakan sebagai $k$. Downtime alat yang disebabkan PM sampai dengan saat $T$ adalah :

$$
P(T)=k
$$

Menurut Soepardi dan Iskandar [5] misalkan $\mathrm{D}(T)$ adalah total lama alat berada pada status down, baik yang disebabkan oleh CM dan kejadian PM sampai dengan saat $T$, yaitu:

$$
\begin{aligned}
& D(T)=E[C(T)]+P(T) \\
& D(T)=E[C(T)]+k
\end{aligned}
$$

Maka ekspektasi $\mathrm{D}(T)$, total lama alat berada pada status down, baik yang disebabkan oleh CM dan kejadian PM sampai dengan saat $T$, diberikan oleh

$$
E[D(T)]=E(X) \int_{0}^{T} \rho(t) d t+k
$$

\section{Penentuan Model Total Biaya Pemeliharaan}

Ekspektasi total biaya pemeliharaan alat selama interval $(0, T]$ merupakan penjumlahan dari total biaya PM, ekspektasi biaya CM, dan ekspektasi biaya kerugian

$$
\begin{aligned}
& E C_{T}=C s+E C_{R}+E C_{L} \\
& E[T C(T)]=c_{S}+c_{r} \int_{0}^{T} \rho(t) d t+c_{l}\left[k+\left(E(X) \int_{0}^{T} \rho(t) d t\right)\right]
\end{aligned}
$$


Ekspektasi total biaya pemeliharaan per siklus kegiatan PM adalah:

$$
E[T C]=\frac{c_{S}}{T}+\frac{c_{r}}{T} \int_{0}^{T} \rho(t) d t+\frac{c_{l}}{T}\left[k+\left(E(X) \int_{0}^{T} \rho(t) d t\right)\right]
$$

\section{Dimana :}

$\mathrm{C}_{\mathrm{S}}$ : total biaya PM yaitu biaya kegiatan PM yang dilakukan secara periodik pada interval konstan.

$E_{R}$ : ekspektasi biaya $C M$ dengan $C_{R}$ merupakan biaya kegiatan $C M$, baik berupa perbaikan maupun penggantian komponen karena kerusakan alat

$\mathrm{EC}_{\mathrm{L}}$ : ekspektasi biaya kerugian dengan $\mathrm{C}_{\mathrm{L}}$ menunjukkan besarnya kerugian yang disebabkan karena downtime alat, baik karena PM maupun karena CM.

Setelah penentuan model biaya total pemeliharaan, dilakukan penentuan $T$ optimal ( $T^{*}$ ) yaitu interval pemeliharaan pencegahan yang dapat meminimasi biaya total pemeliharaan. $T^{*}$ didapat dengan cara mendeferensiasikan model biaya total pemeliharaan pencegahan per siklus (per interval pemeliharaan pencegahan) terhadap $T$.

$$
\begin{aligned}
& \frac{d E[T C]}{d T}=\frac{-c_{s}}{T^{2}}+(b-1) c_{r} a T^{b-2}+\left(\frac{-c_{l} k}{T^{2}}\right)+(b-1) c_{l} E(X) a T^{b-2} \\
0 & =\frac{-c_{s}}{T^{2}}+(b-1) c_{r} a T^{b-2}+\left(\frac{-c_{l} k}{T^{2}}\right)+(b-1) c_{l} E(X) a T^{b-2} \\
0 & =\frac{-c_{s}}{T^{2}}+\frac{(b-1) a T^{b}}{T^{2}}-\frac{c_{l} k}{T^{2}}-\frac{(b-1) c_{l} E(X) a T^{b}}{T^{2}} \\
0 & =\frac{-c_{s}}{T^{2}}+\frac{(b-1) a T^{b}\left(c_{r}+c_{l} E(X)\right)}{T^{2}}-\frac{c_{l} k}{T^{2}} \\
0 & =\frac{-c_{s}-c_{l} k+(b-1) a T^{b}\left(c_{r}+c_{l} E(X)\right)}{T^{2}} \\
0 & =-c_{s}-c_{l} k+(b-1) a T^{b}\left(c_{r}+c_{l} E(X)\right) \\
c_{s}+ & c_{l} k=(b-1) a T^{b}\left(c_{r}+c_{l} E(X)\right) \\
T^{b}= & \frac{c_{s}+c_{l} k}{(b-1) a\left(c_{r}+c_{l} E(X)\right)} \\
T^{*}= & {\left[\frac{c_{s}+c_{l} k}{(b-1) a\left(c_{r}+c_{l} E(X)\right)}\right]^{\frac{1}{b}} }
\end{aligned}
$$

\section{Contoh Numerik}

Nilai parameter untuk contoh numerik pada model ini diambil dari studi kasus sistem pemeliharaan jaringan penyulang listrik 20kV Gombong IV PT. PLN (Persero) APJ Cilacap. Berikut ini dijelaskan parameter yang digunakan:

a) Biaya satu kali melakukan PM dinyatakan sebagai $\mathrm{C}_{\mathrm{s}}$ sebesar $\mathrm{Rp} 117.434,00$. Termasuk biaya PM adalah biaya pemborongan pekerjaan PM yang kegiatannya terdiri dari 
rabas-rabas pohon, pengecatan, pengukuran beban feeder, pengukuran beban trafo, dan pemeliharaan trafo.

b) Biaya satu kali melakukan CM, dinyatakan sebagai $\mathrm{C}_{\mathrm{r}}$ sebesar Rp 46.845,00. Termasuk biaya CM adalah biaya pemborongan per pekerjaan yang didapat dari rata-rata biaya pembongkaran dan pemasangan komponen. Biaya CM tidak memperhitungkan biaya penggantian komponen.

c) Biaya kerugian (loss production) tiap satuan waktu yang disebabkan downtime dinyatakan sebagai $\mathrm{c}_{1}$. sebesar Rp 9.561.403,00. Biaya kerugian merupakan harga listrik per satuan waktu yang tidak diterima PLN dari konsunen karena padam.

d) Rata-rata lama downtime yang disebabkan karena kegiatan PM adalah 4 jam (0,1667 hari) per kegiatan.

e) Koefisien $a$ dan $b$ pada fungsi intensitas $\rho(t)$, berturut-turut adalah 0,12 dan 1,25.

f) Ekspektasi waktu perbaikan $\mathrm{E}(\mathrm{X})$ sebesar 0,03 hari per kegiatan, dimana $\mathrm{X}$ adalah lama downtime yang berdistribusi eksponensial.

Dengan memasukkan nilai-nilai parameter di atas pada Persamaan (12) akan diperoleh interval waktu pencegahan optimal adalah 58 hari.

\section{HASIL DAN PEMBAHASAN}

Faktor yang menjadi perhatian pada model pemeliharaan ini adalah karakteristik alat dan kebijakan pemeliharaan yang dilakukan. Karakteristik alat berhubungan dengan performansi alat yang dipengaruhi oleh faktor intrinsik, yaitu spesifikasi fisik peralatan (material, fungsi dan konfigurasi komponen-komponen penyusun alat) dan faktor ekstrinsik, yaitu berkaitan dengan kondisi lingkungan dimana alat dipakai dan cara menggunakannya. Sedangkan kebijakan pemeliharaan yang diterapkan perusahaan menentukan kegiatan PM yang dilakukan Dua faktor tersebut di atas akan mempengaruhi pola atau distribusi kerusakan alat. Pola kerusakan ini yang selanjutnya dihubungkan dengan terjadinya kerusakan dan downtime alat.

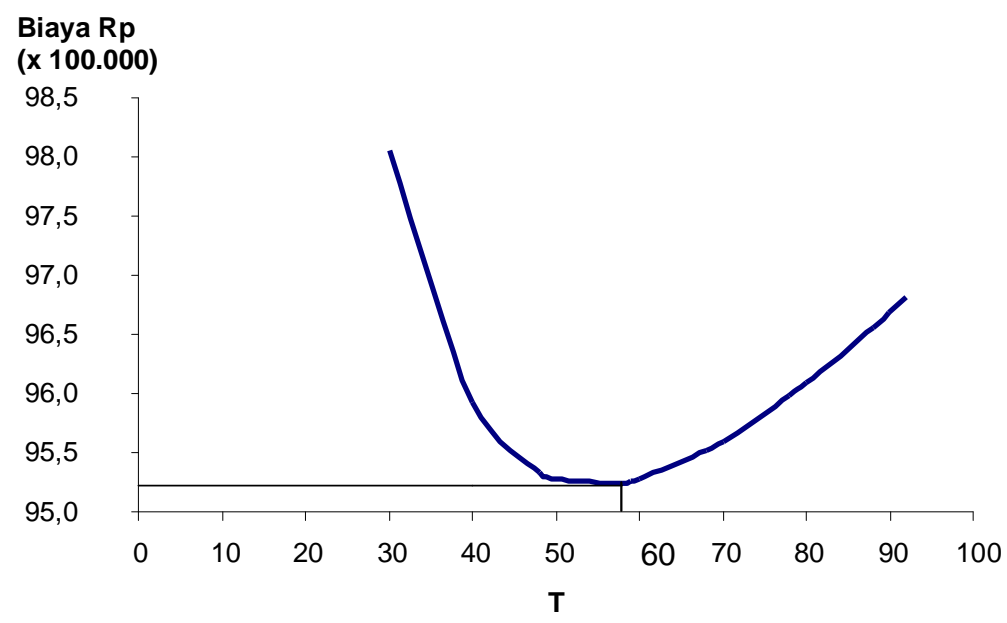

Gambar 1. Kurva biaya total pemeliharaan jaringan

Asumsi-asumsi yang digunakan dalam model ini adalah sebagai berikut:

1. Sifat PM mengembalikan alat pada kondisi baru (as good as new).

2. Perbaikan yang dilakukan di antara kegiatan pemeliharaan pencegahan (di dalam selang PM) bersifat minimal repair, dimana perbaikan tidak mengembalikan alat pada kondisi 
baru sebelum kerusakan, melainkan hanya menjadikan laju kerusakan sama dengan laju kerusakan alat sebelum mengalami kerusakan.

3. Kerusakan suatu komponen tidak mempengaruhi komponen lain.

4. Suku cadang yang diperlukan selalu tersedia.

5. Kemampuan (skill) maintenance crew pada tingkat normal.

Pada model ini yang menjadi parameter adalah biaya pemeliharaan pencegahan $\left(\mathrm{C}_{\mathrm{s}}\right)$, biaya pemeliharaan perbaikan $(\mathrm{Cr})$, dan biaya kerugian $\left(\mathrm{C}_{\mathrm{l}}\right)$. Berdasarkan perhitungan analisis sensitivitas, didapat bahwa masing-masing faktor error $\mathrm{C}_{\mathrm{s}}$, faktor error $\mathrm{C}_{\mathrm{r}}$, dan faktor error $\mathrm{C}_{1}$ menyebabkan perubahan yang seimbang pada perubahan biaya total pemeliharaan, baik pada saat underestimate maupun pada saat overestimate.

Selain ketiga parameter di atas, perubahan interval pemeliharaan pencegahan $(T)$ juga mempengaruhi peningkatan biaya total pemeliharaan. Hal ini disebabkan karena interval pemeliharaan pencegahan mempengaruhi frekuensi pelaksanaan kegiatan pemeliharaan pencegahan. Selain itu, interval pemeliharaan pencegahan juga mempengaruhi jumlah kerusakan yang terjadi pada periode pemeliharaan pencegahan. Kedua hal tersebut mempengaruhi lama downtime jaringan sebagai akibat dilakukannya pemeliharaan pencegahan maupun pemeliharaan perbaikan. Untuk perubahan parameter $T$ terdapat perbedaan peningkatan biaya total pemeliharaan pada saat $T$ lebih kecil maupun lebih besar dari $T$ optimal yang ditunjukkan pada Tabel 1.

Tabel 1. Efek error $T$ pada peningkatan total biaya pemeliharaan

$\begin{array}{ccc}\boldsymbol{T} & \text { Faktor Error } \boldsymbol{T} & \begin{array}{c}\text { Peningkatan TC Pemeliharaan } \\ \mathbf{( \% )}\end{array} \\ 30 & 0.5172 & 2.9601 \\ 38 & 0.6552 & 1.0052 \\ 40 & 0.6897 & 0.7262 \\ 41 & 0.7069 & 0.6089 \\ 42 & 0.7241 & 0.5046 \\ 44 & 0.7586 & 0.3314 \\ 45 & 0.7759 & 0.2607 \\ 48 & 0.8276 & 0.1028 \\ 50 & 0.8621 & 0.0364 \\ 58 & 1.0000 & 0 \\ 60 & 1.0344 & 0.0343 \\ 68 & 1.1724 & 0.2887 \\ 70 & 1.2069 & 0.3750 \\ 71 & 1.2241 & 0.4208 \\ 72 & 1.2414 & 0.4683 \\ 74 & 1.2759 & 0.5679 \\ 75 & 1.2931 & 0.6197 \\ 76 & 1.3103 & 0.6729 \\ 78 & 1.3448 & 0.7828 \\ 80 & 1.3793 & 0.8971\end{array}$


Berdasarkan Tabel 1 terlihat bahwa perubahan yang sama besar pada peningkatan maupun penurunan nilai $T$, mengakibatkan peningkatan yang tidak sama besar terhadap biaya total pemeliharaan pada sisi underestimate maupun pada sisi overestimate. Misal kenaikan $T$ sebanyak 10 hari $(T=68)$ mengakibatkan peningkatan biaya total pemeliharaan sebesar $0.2887 \%$, sedangkan penurunan $T$ sebanyak 10 hari $(T=48)$ mengakibatkan peningkatan biaya total pemeliharaan sebesar $0.1028 \%$. Penurunan nilai $T$ sampai $T=41$ (penurunan $T$ sebesar 17 hari), menyebabkan peningkatan biaya total pemeliharaan yang lebih kecil, jika dibandingkan dengan peningkatan $T$ sebesar 17 hari $(T=75)$. Namun mulai saat $T=76$, peningkatan biaya total pemeliharaan pada sisi overestimate menjadi lebih kecil jika dibandingkan dengan sisi underestimate.

Walaupun demikian, sebaiknya dilakukan overestimate terhadap $T$, yaitu interval pemeliharaan pencegahan dibulatkan menjadi 60 hari (2 bulan). Hal ini disebabkan karena tidak biasa untuk menjadwalkan pemeliharaan pencegahan setiap 58 hari sekali. Lebih mudah untuk menjadwalkan pemeliharaan pencegahan setiap 60 hari (2 bulan) sekali. Selain itu, model ini juga tidak sensitif terhadap perubahan nilai $T$. Hal ini terbukti bahwa peningkatan nilai $T$ sebesar $51.72 \%$ hanya menyebabkan peningkatan biaya total pemeliharaan sebesar 1.3882\%. Sebaliknya, penurunan nilai $T$ sebesar $51.72 \%$ menyebabkan peningkatan biaya total pemeliharaan sebesar $2.9601 \%$.

\section{KESIMPULAN}

1. Deviasi relatif total biaya kegiatan pemeliharaan berdasarkan model yang dihasilkan adalah $0.71 \%$ lebih kecil dari total biaya kegiatan pemeliharaan aktual.

2. Perubahan interval pemeliharaan pencegahan tidak terlalu mempengaruhi peningkatan biaya total pemeliharaan alat sehingga dapat dikatakan bahwa model yang diperoleh tidak sensitif terhadap perubahan interval waktu pemeliharaan pencegahan.

3. Sedangkan jika dilakukan perubahan parameter biaya pemeliharaan pencegahan dan biaya kerugian maka model ini relatif sensitif karena akan terjadi perubahan cukup signifikan terhadap biaya total pemeliharaan jaringan sehingga sebaiknya dilakukan overestimate terhadap dua komponen biaya tersebut untuk mengantisipasi peningkatan total biaya pemeliharaan.

\section{DAFTAR PUSTAKA}

[1] Ebeling, C.E., 1997, An Introduction to Reliability and Maintainability Engineering, McGraw-Hills Company, Singapore.

[2] Murthy, D.N.P. and Asgharizadeh, E., 1998, A Stochastic Model for Service Contract, International Journal of Reliability, Quality in Maintenance, and Safety Engineering, Vol. 5, No. 1, p. 29-45.

[3] Osaki, S., 1992, Applied Stochastic System Modeling, Springer-Verlag, Heidelberg.

[4] Rao, S.S., 1992, Reliability Based Design, McGraw Hill Inc. New York.

[5] Soepardi, A. dan Iskandar, B.P., 2002, Estimasi Ongkos Kontrak Perawatan Alat Berat, Prosiding Seminar Nasional Teknik Industri III Tahun 2002 BKSTI, Surakarta. 